\title{
Numerical Investigation of the Effect of Edge Length of Square Helical Wires on Heat Transfer and Pressure Drop
}

\author{
Taha Tuna Göksu ${ }^{*}$, Rasim Behçet ${ }^{2}$

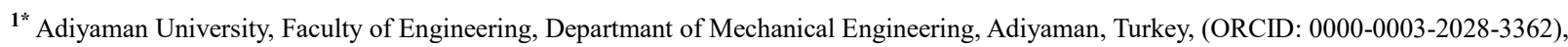 \\ tgoksu@adiyaman.edu.tr \\ ${ }^{2}$ Inonu University, Faculty of Engineering, Departmant of Mechanical Engineering, Malatya, Turkey, (ORCID: 0000-0002-6897-3066), rasim.behcet@inonu.edu.tr
}

(1st International Conference on Applied Engineering and Natural Sciences ICAENS 2021, November 1-3, 2021)

(DOI: 10.31590/ejosat.1009258)

ATIF/REFERENCE: Göksu, T.T, Behçet, R., (2021). Numerical Investigation of the Effect of Edge Length of Square Helical Wires on Heat Transfer and Pressure Drop. European Journal of Science and Technology, (28), 602-606.

\begin{abstract}
Heat transfer and applications are among the most important research topics of the industry. The most important factor investigated in this paper is to achieve high heat transfer with less energy. Efforts to improve heat transfer in heat exchangers are an example of this. In this study, the effect of the length of the square helical wires placed in the circular pipe on the heat transfer and pressure drop was investigated numerically. All results were obtained using the $\mathrm{k}-\varepsilon$ turbulence model in the ANSYS FLUENT module. The equations used in the verification were compared with the Dittus-Boelter equation and the Nusselt number friction factor in the turbulent regime with numerical results. It has been observed that the results of the smooth pipe obtained numerically and the results of the empirical relations are quite close to each other. The cross-sectional length of the inserted helical wires is 3, 4, and $5 \mathrm{~mm}$. The pitch ratio of the placed helical wires is 1 . The Reynolds number research range is between 5175 and 24,575. According to the obtained results, both the Nusselt number and the friction factor increase with increasing edge length. In addition, higher efficiency is obtained at a low Reynolds number according to the thermo-hydraulic thermal performance criterion (PEC). The highest PEC was seen in the helical wire with a crosssection length of $3 \mathrm{~mm}$, with a value of 1.25 . However, it is observed that the PEC of 5 is greater than 4 and 3 with increasing Reynolds number.
\end{abstract}

Keywords: Heat transfer enhancement, FLUENT, Helical coil, Cross-section, PEC

\section{Kare Kesitteki Helisel Tellerin Kenar Uzunluğunun Isı Transferi ve Basınç Düşümüne Etkisinin Sayısal İncelenmesi}

$\ddot{O} z$

Isı transferi uygulamaları endüstrinin en önemli araştırma konuları arasındadır. Sunulan makalede incelenen en önemli faktör, daha az enerji ile yüksek 1sı transferi elde etmektir. Isı eşanjörlerinde 1sı transferini iyileştirme çabaları da buna örnektir. Bu çalışmada dairesel boru içerisine yerleştirilen kare kesitteki helisel tellerin kenar uzunluğunun isı transferi ve basınç düşüşüne etkisi sayısal olarak incelenmiştir. Analizler ANSYS FLUENT modülünde k-E türbülans modeli kullanılarak elde edilmiştir. Doğrulamada kullanılan denklemler, türbülanslı rejimdeki kullanılan Dittus-Boelter denklemiyle Nusselt sayısı ve türbülanslı rejimde kullanılan sürtünme faktörü ile sayısal sonuçlarla karşılaştırılmıştır. Sayısal olarak elde edilen boş boru sonuçları ile ampirik ilişkilerin sonuçlarının birbirine oldukça yakın olduğu görülmüştür. Yerleştirilen sarmal/helisel tellerin kesit uzunluğu 3, 4 ve 5 mm'dir. Yerleştirilen sarmal tellerin hatve oranı 1'dir. Reynolds sayısı araştırma aralığı 5175 ila 24,575 arasındadır. Elde edilen sonuçlara göre kenar uzunluğu arttıkça hem Nusselt sayısı hem de sürtünme faktörü artmaktadır. Ayrıca termo-hidrolik olarak ele alanan termal performans kriterine (PEC) göre düşük Reynolds sayısında daha yüksek verim elde edilmiştir. En yüksek PEC, 1,25 değeri ile 3 mm kesit uzunluğuna sahip sarmal telde görüldü. Ancak artan Reynolds sayısı ile kesit uzunluğu 5 mm'nin PEC'nin 4 ve 3 'ten büyük olduğu görülmektedir.

Anahtar Kelimeler: Isı Transfer İyileştirmesi, FLUENT, Helisel Tel, PEC, Kesit geometrisi.

* Corresponding Author: tgoksu@adiyaman.edu.tr 


\section{Introduction}

Placing the external element inside the heat exchanger, which is one of the passive heat transfer improvement techniques, has an important role in improving the heat transfer. The main reason for this is that it does not bring extra costs. The most important elements or geometries that come to the fore at this point are external elements such as twisted tape or helical wires.

The thermal and hydraulic characteristics of different types of twisted band and helical wires were investigated in both laminar and turbulent regimes. It has been found that helical wire performs better than twisted tape (Wang \& Sundén, 2002).

The analysis of heat transfers and flow-induced vibration in the case of conical rings placed inside the pipe has been experimentally investigated. The pitches of the placed external elements are 10,20, and $30 \mathrm{~mm}$. The conical ring with a pitch of $10 \mathrm{~mm}$ increased the heat transfer by $250 \%$ in the case of constant pump power (Yakut \& Sahin, 2004).

The effect of helical wire in 3 different pitches, where the fluid is water, on the heat transfer when placed in the pipe was numerically investigated. According to the results obtained, the maximum thermal stress was observed when the pitch ratio $(\mathrm{p} / \mathrm{D})$ was 2 and the speed was $3 \mathrm{~m} / \mathrm{s}$ (Özceyhan, 2005).

The effect of helical wires on heat transfer and pressure drop in circular cross-section, 6 different geometries, $\mathrm{p} / \mathrm{D}$ ratio in the range of 1.17 to 2.68 , and also the ratio of cross-section diameter to pipe diameter (e/D) 0.07 to 0.1 were investigated experimentally. Helical wire placed at constant pumping power and in the transition zone increased the heat transfer by $200 \%$. The placed helical wires showed the highest efficiency in the transition region (García et al., 2005).

The effect of geometric parameters such as pitch effect on heat transfer when helical wire elements are placed inside the double pass heat exchanger has been investigated. According to the results of the experiments, they observed the effect of placing an external element/turbulator on heat transfer, especially in the laminar region (Gunes et al., 2010).

The effect of conical-nozzle and combined type swirl generator (the use of conical nozzle and volute geometry together) on the heat transfer improvement when placed in the pipe at different pitch ratios was experimentally investigated. According to the experimental results obtained, they observed that the conical nozzle or volute type combined turbulator increased the heat transfer by $278 \%$ and $206 \%$, respectively (Promvonge \& Eiamsa-ard, 2006, p.).

The properties of the boiling heat transfer of nitrogen were investigated experimentally when the helical wires were placed inside the tube. The inserted helical wire has a circular crosssection geometry. The realized heat transfer improvement increased by $174 \%$ compared to the smooth pipe (Yun et al., 2007).

The effect of conical turbulators with converging and diverging geometry on heat transfer has been experimentally investigated. Pitch ratios are $\mathrm{p} / \mathrm{D}=2.0,4.0$ and 7.0. According to the results obtained, an increase of $315 \%, 300 \%$ and $285 \%$ was observed for the specified pitch ratios compared to the Nusselt number smooth pipe, respectively (Promvonge \& Eiamsa-ard, 2007).
The thermal and hydraulic characteristics of the twisted tape and wire nails type geometries placed on the twisted tape were experimentally investigated. Twisting ratios (Y) of the placed twisted tape or spiked twisted tape are $\mathrm{Y}=2,4.4$ and 6 . According to the experimental results obtained, the highest Thermal Performance Factor (PEC) was observed as 1.33 in the spiked twisted tape. They obtained this value at low Reynolds number and $Y=2$. The lowest PEC was observed in the case of $Y=6$ and in the straight twisted band, but at a high Reynolds number(Murugesan et al., 2010) .

The effect on heat transfer was investigated by placing the fin-type turbulators in the channel with a Reynolds number of 4,000 to 23,000 . Working pitch values are 1,2 and 3 . The highest $\mathrm{PEC}=1.8$ was obtained at low Reynolds number and $\mathrm{p} / \mathrm{D}=1$ (Promvonge et al., 2012) .

Energy and exergy analysis were made by placing twisted tape or strip and their derivatives integrated into the humidification-dehumidification desalination system (Muthusamy \& Srithar, 2015).

The variation in the heat transfer coefficient when the bent strip is placed in the pipe at different pitch ratios (6-9) has been numerically investigated. Results showed that the heat transfer performance or Thermal Performance Factor (PEC) is 0.90-1.02, $0.89-1.00,0.91-0.96$, and $0.92-0.96$, respectively, depending on the increase in twist rate (Göksu \& Yilmaz, 2019).

In this study, the effect of the edge length of the helical wire on the heat transfer improvement was investigated. The crosssection of the studied geometry is square. The section lengths whose effects on heat transfer were investigated are 3, 4, and 5 $\mathrm{mm}$. The Reynolds number research range is between 5175 and 24,575 .

\section{Numerical Approach}

\subsection{Geometry}

Figure 1 shows the geometry of helical insert placed in a plain tube. The inlet diameter of the pipe is $60.3 \mathrm{~mm}$ and the thickness of the pipe is $3.5 \mathrm{~mm}$. The geometry of helical wire with a pipe was modeled periodically. Figure 1 shows the periodical geometry of the pipe with placed helical coil/wire. The geometrical crosssection of the helical coil is square and each side of a square is $\mathrm{a}=3,4$, and $5 \mathrm{~mm}$. Pitch ratio of whole geometries are equal to $\mathrm{p} / \mathrm{D}=1$.

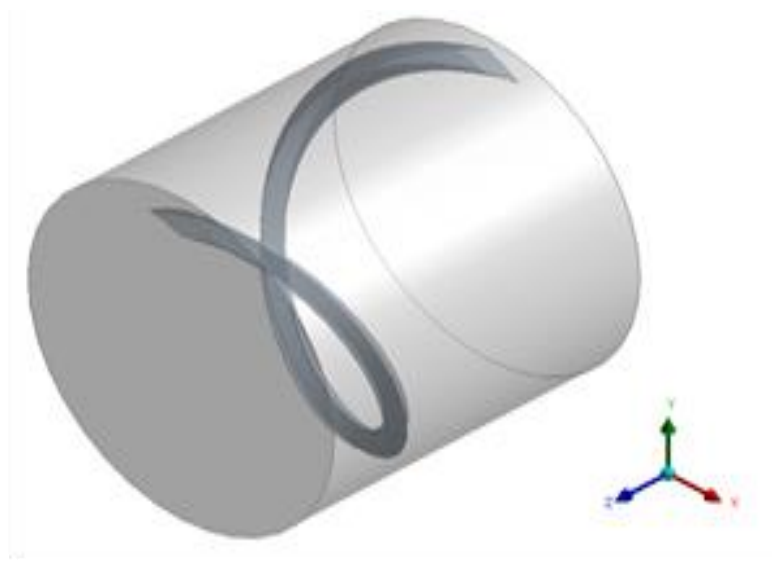

Fig.1. Geometry of periodical model 


\subsection{Mesh}

Plain tube mesh, mesh for $\mathrm{a}=3,4$, and $5 \mathrm{~mm}$ were applied to the geometry for analysis. The full model geometry meshed for the plain tube analysis, and for the geometries where the edge length effect of square wire coil was investigated, less mesh was applied because the periodic model was used. Tetra mesh was applied to all geometries first. Then all meshes were converted to polyhedral meshes. The lowest quality (for orthogonal quality) for all analyzes was obtained as 0.125 , and this value is very important to get accurate results in the program.

Tetrahedral mesh numbers are 240097, 246154, and 250470 for $\mathrm{a}=3,4$, and $5 \mathrm{~mm}$, respectively. The number of elements was increased up to 3 times and tested again, and the specified mesh numbers were used after it was seen that the deviation amount obtained was below $0.98 \%$. Figure 2 and 3 show the tetra mesh of domain, converted mesh for polyhedral meshes, respectively.

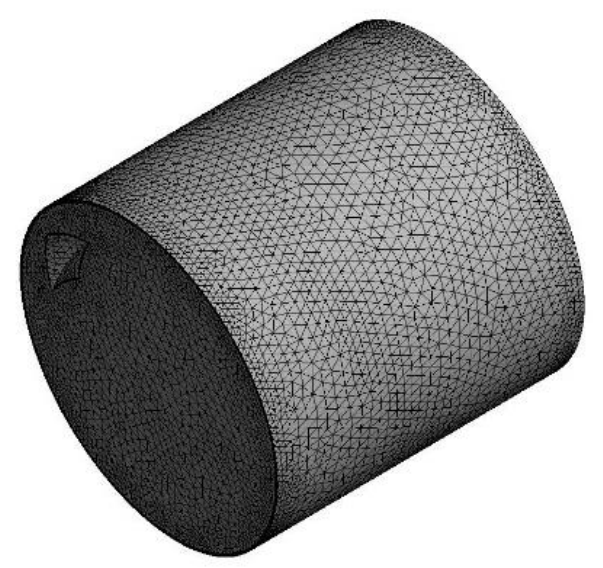

Fig.2. Tetrahedral mesh for domain

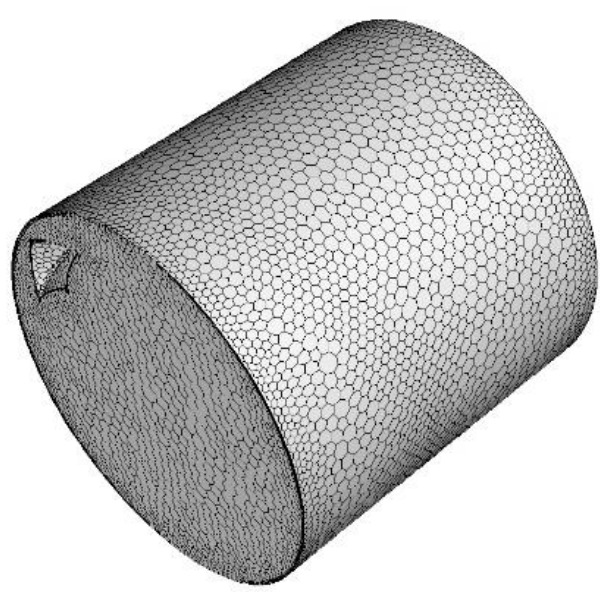

Fig.3. Tetrahedral mesh converted to polyhedral mesh

\subsection{Boundary condition}

The flow direction is specified as normal to the tube crosssection. Uniform heat flux was performed on the pipe wall as 500 $\mathrm{W} / \mathrm{m} 2$. The air was selected to be the working fluid. The flow regime is considered to be turbulent where the Reynolds number varies from 5175 to 24,556 .

\subsection{Numerical solution}

The commercial computational fluid dynamics(CFD) solver Ansys Fluent was used. SIMPLE algorithm for pressure-velocity coupling, spatial discretization for gradient (least square cellbased), pressure (second-order), turbulent kinetic energy and dissipation rate (first-order upwind), momentum, and energy (second-order upwind) and k- $\varepsilon$ turbulence model with enhanced wall treatment option were applied. The $y+$ value was lower than 1 for all analyses. The solution convergence criterion was satisfied as to the scaled residuals less than 10-7 for energy, and 10-4 for momentum, continuity, $\mathrm{k}$, and $\varepsilon$.

\subsection{Calculation of Thermo-Hydraulic Fluid Properties}

The following equations were used for the calculation of numerical results:

Reynolds Number (Re):

$$
\operatorname{Re}=\frac{\rho \cdot U_{\text {ort }} \cdot D_{h}}{\mu}
$$

Darcy's friction factor (f):

$$
f=\frac{2 \cdot \Delta P \cdot D}{\rho \cdot U_{\text {mean }}^{2} \cdot L}
$$

Blasius equation for plain tube friction under turbulent flow:

$$
\mathrm{f}=\frac{0.316}{\operatorname{Re}^{0.25}}
$$

Nusselt number( $\mathrm{Nu})$ :

$$
\mathrm{Nu}=\frac{\mathrm{h} \cdot \mathrm{D}_{h}}{\mathrm{k}}
$$

Dittus-Boelter equation for plain tube:

$$
\mathrm{Nu}=0.023 \cdot \mathrm{Re}^{0.8} \operatorname{Pr}^{0.4}
$$

Performance evaluation criteria (PEC):

$$
\operatorname{PEC}=\eta=\left.\frac{h_{a}}{h_{0}}\right|_{p p}=\left.\frac{N u_{a}}{N u_{0}}\right|_{p p}=\left(\frac{N u_{a}}{N u_{0}}\right)\left(\frac{f_{a}}{f_{0}}\right)^{-1 / 3}
$$

\section{Results and Discussion}

Figures 4 and 5 show the smooth pipe comparisons of the numerical with experimental results of Reynolds number versus Nusselt number and friction factor. Figures shows that, the results of the Nusselt number and Darcy's friction factor are close for the Reynolds number range of 5175 and 24,575 . While the deviation of the numerical results for the Nusselt number varies between $2.3-12.8 \%$, it is between $4.3-14.3 \%$ for the friction factor. 


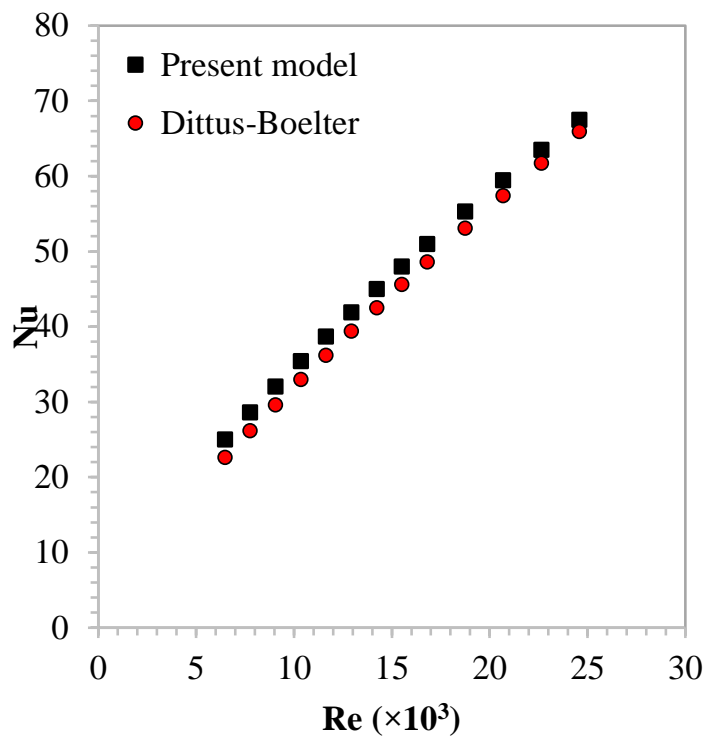

Fig.4. Nusselt number comparison with Numerical and Experimental

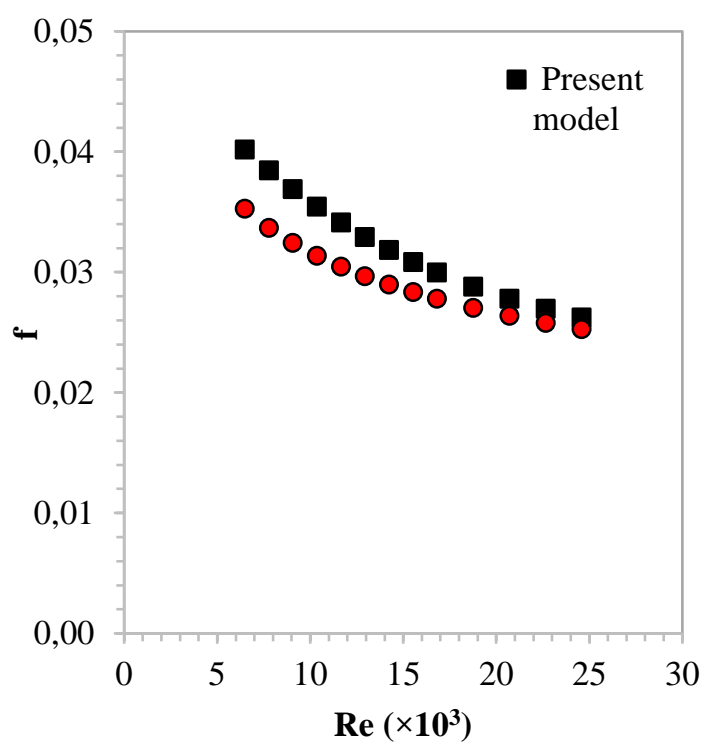

Fig.5. Friction factor comparison with Numerical and Experimental

Figures 6,7 , and 8 show the variation of Nusselt number, friction factor, and PEC with respect to Reynolds number, respectively. It was observed that Nusselt number of $\mathrm{a}=5 \mathrm{~mm}$ were higher than $\mathrm{a}=4 \mathrm{~mm}$ and $\mathrm{a}=3 \mathrm{~mm}$, respectively, throughout the entire Reynolds number. The highest Nusselt number was obtained as $\mathrm{Nu}=134.7$ in $\mathrm{Re}=24,564$, and the lowest $\mathrm{Nu}=103.29$ in this Reynolds number was obtained at $\mathrm{a}=3 \mathrm{~mm}$.

The highest friction factor for all Reynolds numbers was observed at $\mathrm{a}=5 \mathrm{~mm}$. followed by $\mathrm{a}=4$ and $\mathrm{a}=3 \mathrm{~mm}$, respectively. the highest friction factor was obtained as $\mathrm{f}=0.522$ at low Reynolds number.

When the graph of Reynolds number against PEC is examined, the highest $\mathrm{PEC}=1.25$ is seen at low Reynolds number and $a=3 \mathrm{~mm}$, while $a=5 \mathrm{~mm}$ outperforms the other two length $\mathrm{a}=3$, $4 \mathrm{~mm}$ as the Reynolds number increases.

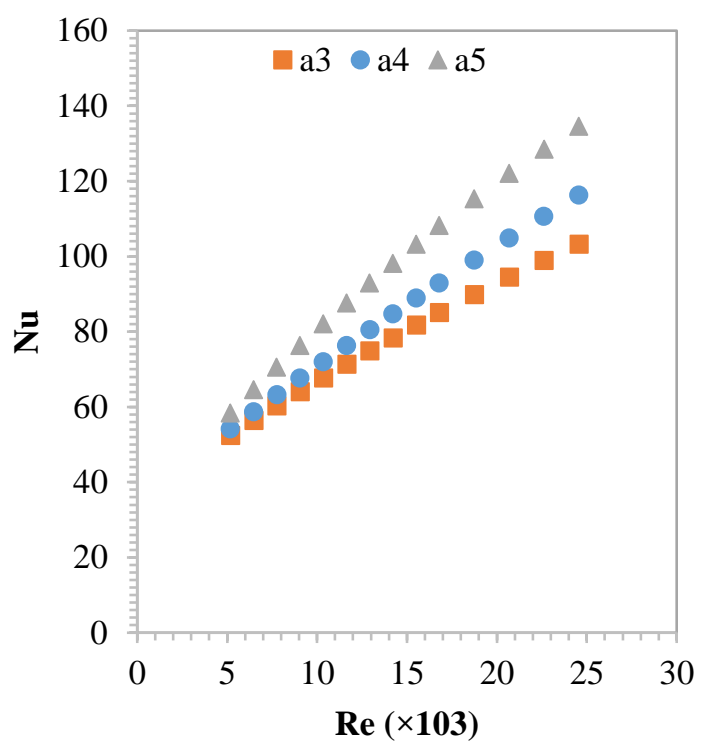

Fig.5. Nusselt number variation with edge length

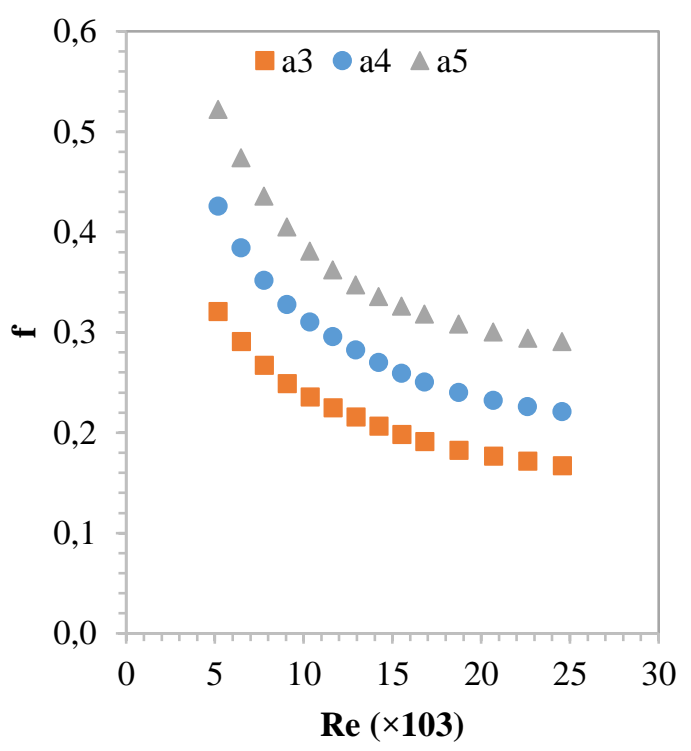

Fig.7. Friction factor variation with edge length

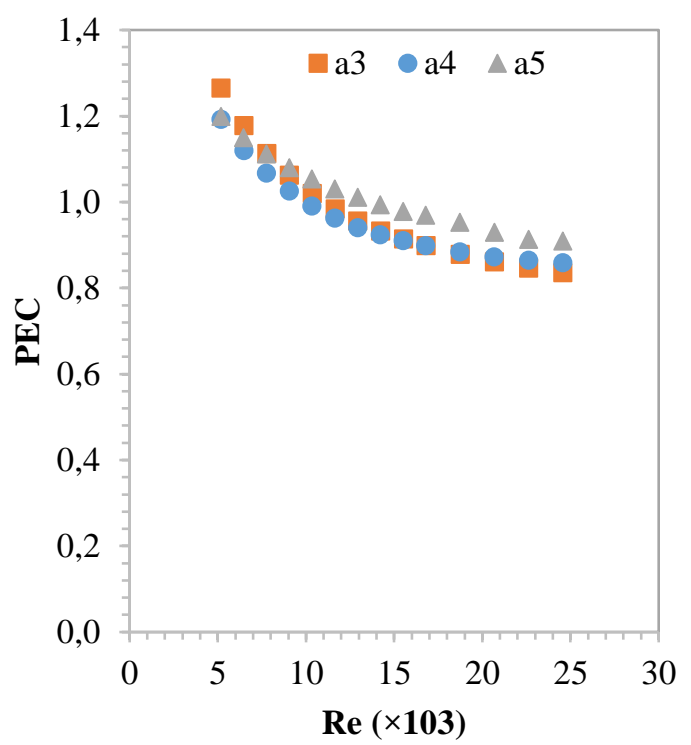

Fig.6. PEC variation with edge length 


\section{Conclusions}

This paper presents the thermo-hydraulic performance of helical coil placed in pipe with length of coil. A numerical model has been developed periodically. Each side of square helical coil is 3,4 , and $5 \mathrm{~mm}$. pitch ratio is $\mathrm{p} / \mathrm{D}=1$ for the Reynolds number range of 5175 to 24,575 . The findings of the numerical study which reveal how efficiently this insert is to be utilized for enhancing the heat transfer against pressure drop are as follows:

$>$ The highest friction factor and Nusselt number for all Reynolds numbers were found at $\mathrm{a}=5 \mathrm{~mm}$.

$>$ The best thermal performance was observed at $a=5$ $\mathrm{mm}$ in all tests except the low Reynolds number.

$>$ The highest $\mathrm{PEC}=1.25$ was obtained at low Reynolds number.

$>$ The effect of the helical wire of the specified crosssection on the heat transfer was observed when the Reynolds number is less than $=10,000$.

\section{Acknowledge}

The authors acknowledge the financial support received from the Scientific Research Project Unit of Inonu University under Grant no. FDK-2020-2286.

\section{References}

García, A., Vicente, P. G., \& Viedma, A. (2005). Experimental study of heat transfer enhancement with wire coil inserts in laminar-transition-turbulent regimes at different Prandtl numbers. International Journal of Heat and Mass Transfer, 48(21-22), 4640-4651. https://doi.org/10.1016/j.ijheatmasstransfer.2005.04.024

Göksu, T. T., \& Yilmaz, İ. H. (2019). Enhancement of heat transfer using twisted tape insert in a plain tube. 10.

Gunes, S., Ozceyhan, V., \& Buyukalaca, O. (2010). Heat transfer enhancement in a tube with equilateral triangle cross sectioned coiled wire inserts. Experimental Thermal and Fluid Science, 34(6), 684-691. https://doi.org/10.1016/j.expthermflusci.2009.12.010

Murugesan, P., Mayilsamy, K., \& Suresh, S. (2010). Heat Transfer and Friction Factor Studies in a Circular Tube Fitted with Twisted Tape Consisting of Wire-nails. Chinese Journal of Chemical Engineering, 18(6), 1038-1042. https://doi.org/10.1016/S1004-9541(09)60166-X

Muthusamy, C., \& Srithar, K. (2015). Energy and exergy analysis for a humidification-dehumidification desalination system integrated with multiple inserts. Desalination, 367, 49-59. https://doi.org/10.1016/j.desal.2015.03.032

Özceyhan, V. (2005). Conjugate heat transfer and thermal stress analysis of wire coil inserted tubes that are heated externally with uniform heat flux. Energy Conversion and Management, 46(9-10), $1543-1559$ https://doi.org/10.1016/j.enconman.2004.08.003

Promvonge, P., \& Eiamsa-ard, S. (2006). Heat transfer enhancement in a tube with combined conical-nozzle inserts and swirl generator. Energy Conversion and Management, 47(18-19), $2867-2882$ https://doi.org/10.1016/j.enconman.2006.03.034

Promvonge, P., \& Eiamsa-ard, S. (2007). Heat transfer in a circular tube fitted with free-spacing snail entry and conicalnozzle turbulators. International Communications in Heat and Mass Transfer, 34(7), 838-848. https://doi.org/10.1016/j.icheatmasstransfer.2007.03.020

Promvonge, P., Skullong, S., Kwankaomeng, S., \& Thiangpong, C. (2012). Heat transfer in square duct fitted diagonally with angle-finned tape-Part 1: Experimental study. International Communications in Heat and Mass Transfer, 39(5), 617-624. https://doi.org/10.1016/j.icheatmasstransfer.2012.03.007

Wang, L., \& Sundén, B. (2002). Performance comparison of some tube inserts. International Communications in Heat and Mass Transfer, 29(1), 45-56. https://doi.org/10.1016/S07351933(01)00323-2

Yakut, K., \& Sahin, B. (2004). Flow-induced vibration analysis of conical rings used for heat transfer enhancement in heat exchangers. Applied Energy, 78(3), 273-288. https://doi.org/10.1016/j.apenergy.2003.09.001

Yun, R., Hwang, J.-S., Chung, J. T., \& Kim, Y. (2007). Flow boiling heat transfer characteristics of nitrogen in plain and wire coil inserted tubes. International Journal of Heat and Mass Transfer, 50(11-12), 2339-2345. https://doi.org/10.1016/j.ijheatmasstransfer.2006.10.038 